University of Nebraska - Lincoln

DigitalCommons@University of Nebraska - Lincoln

USGS Northern Prairie Wildlife Research Center

US Geological Survey

2012

\title{
Bird Productivity and Nest Predation in Agricultural Grasslands
}

\author{
C.A. Ribic \\ Wisconsin Cooperative Wildlife Research Unit, caribic@wisc.edu \\ Michael Guzy \\ University of Wisconsin, mjguzy@charter.net \\ Travis Anderson \\ University of Wisconsin, travis.anderson@wisconsin.gov \\ David Sample \\ Wisconsin Department of Natural Resources, david.sample@wisconsin.gov \\ Jamie Nack \\ University of Wisconsin, jlnack@wisc.edu
}

Follow this and additional works at: https://digitalcommons.unl.edu/usgsnpwrc

Part of the Other International and Area Studies Commons

Ribic, C.A.; Guzy, Michael; Anderson, Travis; Sample, David; and Nack, Jamie, "Bird Productivity and Nest Predation in Agricultural Grasslands" (2012). USGS Northern Prairie Wildlife Research Center. 257. https://digitalcommons.unl.edu/usgsnpwrc/257

This Article is brought to you for free and open access by the US Geological Survey at DigitalCommons@University of Nebraska - Lincoln. It has been accepted for inclusion in USGS Northern Prairie Wildlife Research Center by an authorized administrator of DigitalCommons@University of Nebraska - Lincoln. 


\title{
Bird Productivity and Nest Predation in Agricultural Grasslands
}

\author{
Christine A. Ribic, Michael J. Guzy, Travis J. Anderson, \\ David W. Sample, and Jamie L. Nack
}

Abstract. Effective conservation strategies for grassland birds in agricultural landscapes require understanding how nesting success varies among different grassland habitats. A key component to this is identifying nest predators and how these predators vary by habitat. We quantified nesting activity of obligate grassland birds in three habitats [remnant prairie, cool-season grass Conservation Reserve Program (CRP) fields, and pastures] in southwest Wisconsin, 2002-2004. We determined nest predators using video cameras and examined predator activity using track stations. Bobolink (Dolichonyx oryzivorus) and Henslow's Sparrow (Ammodramus henslowii) nested primarily in CRP fields, and Grasshopper Sparrow (A. savannarum) in remnant prairies. Eastern Meadowlark (Sturnella magna) nested evenly across all three habitats. Daily nest survival rate for Eastern Meadowlark varied by nesting stage alone. Daily nest survival rate for Grasshopper Sparrow varied by nest vegetation and distance to the nearest woody edge; nest survival was higher near woody edges. In CRP fields, most predators were grassland-associated, primarily thirteen-lined ground squirrels (Ictidomys tridecemlineatus). In pastures, one-third of the nest predators were grassland-associated (primarily thirteen-lined ground squirrels) and 56\% were associated with woody habitats (primarily raccoons, Procyon lotor). Raccoon activity was greatest around pastures and lowest around prairies; regardless of habitat, raccoon activity along woody edges was twice that along non-woody edges. Thirteen-lined ground squirrel activity was greater along prairie edges than pastures and was greater along nonwoody edges compared to woody edges. In CRP fields, raccoon activity was greater along edges compared to the interiors; for ground squirrels these relationships were reversed. Using video camera technology to identify nest predators was indispensable in furthering our understanding of the grassland system. The challenge is to use that knowledge to develop management actions for both birds and predators.

Key Words: agriculture, Conservation Reserve Program, grassland birds, nest predators, nesting success, pastures, remnant prairie, thirteen-lined ground squirrel.

Ribic, C. A., M. J. Guzy, T. J. Anderson, D. W. Sample, and J. L. Nack. 2012. Bird productivity and nest predation in agricultural grasslands. Pp. 119-134 in C. A. Ribic, F. R. Thompson III, and P. J. Pietz (editors). Video surveillance of nesting birds. Studies in Avian Biology (no. 43), University of California Press, Berkeley, CA.

This article is a U.S. government work, and is not subject to copyright in the United States. 
$\mathrm{s}$ a result of widespread and steep population declines, many grassland bird species are now of conservation concern at both state and federal levels (Askins et al. 2007). Alteration and loss of habitat (including fragmentation) are considered to be among the most important factors in these population declines (Brennan and Kuvlesky 2005, Askins et al. 2007). Grassland birds have faced wholesale changes in habitat since settlement of North America by Europeans. For example, native tallgrass prairie has been reduced to a fraction of its historical acreage in the U.S. (Samson et al. 1998). More recently, the amount of nonnative grasslands has also declined (Askins et al. 2007). In the Midwest, the recent population declines of grassland birds are related to rapid conversion, since the 1950 s, of predominantly grass-based agriculture (e.g., grass hay, pasture, small grains) to one based on intensively farmed habitats more hostile to birds [e.g., row crops and alfalfa (Medicago sativa) hay] (Murphy 2003, Sample et al. 2003).

Much of grassland bird conservation in the Midwest is taking place in agricultural landscapes, and most of the land is privately owned and actively worked (Askins et al. 2007). The paucity of large protected grasslands in public or conservation ownership in these landscapes makes those habitats that remain relatively undisturbed during the breeding season, including remnant prairies, agricultural set-aside fields, idle oldfields and lightly grazed pastures, some of the most valuable habitat for grassland birds (Sample and Mossman 1997, Askins et al. 2007).

The conservation of remnant prairie as a system has become an important conservation focus (Samson and Knopf 1996), and management for grassland birds can contribute to this effort (Askins et al. 2007). Grassland habitat established through federal set-aside programs, such as the Conservation Reserve Program (CRP) (Farm Service Agency Online 2007), are clearly important for grassland birds (e.g., Johnson and Igl 1995, Koford 1999, Gill et al. 2006, Niemuth et al. 2007). Finally, some working grasslands, such as pastures, can be part of a conservation plan for grassland birds as well, depending on how the pastures are managed (Sample and Mossman 1997).

To develop effective conservation strategies in working agricultural landscapes, we need to understand how grassland bird species use different grassland habitat types. Much work has been done on understanding the density patterns of grassland bird species in different habitats (Askins et al. 2007, Ribic et al. 2009b). Less well understood is nesting success of grassland birds in different habitats (Koford 1999, Winter and Faaborg 1999, Herkert et al. 2003, Murray and Best 2003, Kershner et al. 2004, Walk et al. 2004, Gill et al. 2006), particularly comparisons among habitats or planting types (Patterson and Best 1996, Giuliano and Daves 2002, Henningsen and Best 2005, Fletcher et al. 2006).

Because predation is the main cause of nest failure (Martin 1988, 1995), acquiring information on predation is a key component to understanding nest success. Of interest is the presence or lack of edge effects (i.e., an increased rate of nest failure along a habitat transition; Lahti 2001). However, evidence for edge effects in grassland habitats has been equivocal (Lahti 2001, Johnson 2001). Explanations are many, but one important consideration is the identity of the nest predators (Chalfoun et al. 2002). Grassland bird ecologists are beginning to understand that predation on grassland bird nests is not solely due to edge predators (e.g., raccoon, Procyon lotor) and brood parasites (e.g., Brown-headed Cowbird, Molothrus ater), but is also a function of predators that live in the grassland habitat itself (e.g., thirteen-lined ground squirrel, Ictidomys tridecemlineatus) (Pietz and Granfors 2000, Renfrew and Ribic 2003) as well as habitat generalists such as snakes (Thompson et al. 1999, Renfrew and Ribic 2003). Therefore, the relative importance of edge effects will likely depend on the species composition, abundance, and activity of the nest predators (Ribic et al. 2009b).

Some states have started to focus their grassland bird management using a landscape approach (Sample et al. 2003). This will entail focusing management efforts in specific landscapes and understanding the value of different grassland habitats for grassland birds. For effective conservation, it will be especially important for grassland habitats in these targeted landscapes to be "good" for grassland birds, and studying nest success and predator communities is a critical part of this evaluation. We focused on a grasslanddominated landscape in southwestern Wisconsin that has been identified as one of the best areas where landscape-scale management of grassland birds could take place (Sample and Mossman 
1997). Our objectives were to (1) determine nesting activity of grassland birds in remnant prairie patches, CRP fields, and pasture; (2) determine the influence of field vegetation, patch size, and distance to edge on nesting success; (3) determine the nest predators in CRP fields, remnant prairies, and pastures; and (4) quantify predator activity along edges of all habitat types and in the interior of CRP fields.

\section{METHODS}

\section{Study Area}

We conducted our study May-July 2002-2004 in western Dane, eastern Iowa, and northern Green counties of Wisconsin. The study area was located in the Driftless Area, an area that escaped the most recent glacial periods. The study area was 33,413 ha and was bounded on the north by Highway 18-151 between $89^{\circ} 41^{\prime} 47^{\prime \prime} \mathrm{W}$, $43^{\circ} 0^{\prime} 19^{\prime \prime} \mathrm{N}$ and $89^{\circ} 59^{\prime} 36^{\prime \prime} \mathrm{W}, 43^{\circ} 0^{\prime} 37^{\prime \prime} \mathrm{N}$; the southern boundary was between $89^{\circ} 42^{\prime} \mathrm{W}, 42^{\circ} 49^{\prime} 4^{\prime \prime} \mathrm{N}$ and $89^{\circ} 48^{\prime} 42^{\prime \prime} \mathrm{W}, 42^{\circ} 49^{\prime} 18^{\prime \prime} \mathrm{N}$. The topography is a series of ridges and valleys running south from the Military Ridge, an east-west ridge that extends from west of Madison to where the Wisconsin River flows into the Mississippi River. Historically, ridge tops in this landscape were dry and dry-mesic prairie, whereas the draws and valleys were mesic and wet prairie and oak savanna (Curtis 1959, Cochrane and Iltis 2000).

The study area was located in the most important landscape in Wisconsin for grassland bird conservation (Sample and Mossman 1997). Land use was primarily agricultural, with a large portion of the land in pasture, hay, and small grains and relatively few acres of row crops [corn (Zea mays) and soybeans (Glycine max)] compared to many other agricultural areas of Wisconsin. Approximately $27 \%$ of the land area in the study area was in pasture and idle grass at the time of the study. There was a significant concentration of prairie remnants and high enrollment in CRP (Farm Service Agency Online 2007). Densities of individual grassland bird species in the three habitats did not vary among the years of the study (Ribic et al. 2009a).

Sites used for nest searching were randomly chosen from a set of sites used in a larger study evaluating the grassland bird community across a range of habitat types (Ribic et al. 2009a). Patch size was delineated as the specific site and any adjacent contiguous grassland that was the same habitat type; wire fences separating ownerships were not considered borders. Additional detailed descriptions of the habitats can be found in Ribic et al. (2009a).

We used five remnant prairie patches during the study (mean patch size $=11.8$ ha, $\mathrm{SD}=6.0$; range $=8.5-21.9$; mean vegetation height-density $=2.1 \mathrm{dm}, \mathrm{SD}=0.6$ ). Remnant prairies (patches of unplowed sod of native vegetation) were small and found in areas too steep, thin-soiled, or rocky to plow. Virtually all had a history of varying degrees of grazing pressure, and some parts were historically cropped, resulting in a mix of native and Eurasian vegetation and are thus considered disturbed prairies. Relatively little woody vegetation was present and consisted of scattered shrubs, shrub clumps, and small trees. Dominant native grass species included little bluestem (Schizachyrium scoparium), big bluestem (Andropogon gerardii), needle (porcupine) grass (Heterostipa spartea), Indian grass (Sorghastrum nutans), side-oats grama (Bouteloua curtipendula), and panic grass (Panicum spp.).

We used seven CRP fields (mean patch size $=$ $32.2 \mathrm{ha}, \mathrm{SD}=20.9$; range $=10.7-58.2$; mean vegetation height-density $=3.2 \mathrm{dm}, \mathrm{SD}=0.4$ ), and most were enrolled continuously in CRP since 1986-1988. Vegetation consisted of cool-season grasses, primarily smooth brome (Bromus inermis) and a wide variety of forbs.

We used five pastures (mean patch size $=$ 22.6 ha, $\mathrm{SD}=8.6$; range $=10.2-31.0$; mean vegetation height-density $=1.0 \mathrm{dm}, \mathrm{SD}=0.9)$. The dominant grass species was Kentucky bluegrass (Poa pratensis). Weedy forbs such as thistle (Cirsium and Carduus spp.), tufts of grass and forbs adjacent to cowpies, and scattered woody vegetation provided variation in vegetation structure within the pastures. Pastures were used to graze beef cattle; average stocking rate May-July was 0.95 Animal Units/ha (an AU is equivalent to $500 \mathrm{~kg}$ of animal weight) (Forage and Grazing Terminology Committee 1991) ( $\mathrm{SD}=0.29, n=4$; range $=0.63-1.31$.

\section{Nest Searching and Monitoring}

We found nests by having evenly spaced observers drag a 50-m 4-cm diameter sisal rope across the site. Three people pulled the rope and four observers walked behind the rope, looking for birds flushing from nests. We used rope dragging 
until the grass grew to a height where the rope was no longer effective at moving the grass close to the ground. When rope dragging became ineffective, we located nests by having up to 12 observers walk side by side approximately $1.5 \mathrm{~m}$ apart; we used wire flags to mark the edges of the path traveled to facilitate searching the entire area. Sites 10 ha or less were searched in their entirety. We determined the size of the area to search on sites larger than 10 ha by using approximately the same number of observer hours of effort as in the smaller sites.

We recorded nest locations using a Global Positioning System unit. We also tied flagging on vegetation (or, in pastures, sprayed a paint spot on the ground) $4 \mathrm{~m}$ either north or south of the nest (direction was chosen randomly and noted on a card) to reduce the amount of activity required to relocate the nest. We monitored nests every 2-3 days and approached the paint spot from varying directions to avoid creating paths. We minimized time spent near active nests to avoid disturbance. We recorded number of eggs, number of nestlings, development of feathers, nestling size, the presence of adults on or near the nest, and nest fate (including cause of failure). Unless a nest was monitored with a camera, we used egg remains, the condition of the nest and surrounding vegetation, adult behavior, and feces left from fledglings to determine whether the nest was successful or the cause of failure.

\section{Nest Predators in CRP Fields and Remnant Prairie Patches}

We used miniature remote infrared video cameras (Renfrew and Ribic 2003) on randomly selected grassland bird nests in CRP fields and remnant prairies to determine nest fates and causes of failure. We followed many of the recommendations of Richardson et al. (2009) when deploying cameras. We did not cluster the cameras in any one part of the fields. Cameras were placed at a nest during or soon after the egg-laying stage ended to lower the chance of abandonment (Thompson et al. 1999, Renfrew and Ribic 2003). Fewer cameras were used on remnant prairie sites compared to CRP fields due to concerns about theft (remnant prairie sites had public access).

We placed cameras $10-31 \mathrm{~cm}$ from a nest and mounted $10-20 \mathrm{~cm}$ high on a wooden dowel pushed into the ground. Cameras were camouflaged and surrounding grass was pulled over the top for concealment when possible. A cable connecting the camera to a time-lapse video cassette recorder (VCR) located $25 \mathrm{~m}$ away from the nest was carefully concealed on the ground with surrounding dead and live vegetation. We minimized disturbance to the nest by checking nest status with a miniature monitor connected to the VCR and checked VCRs daily to change tapes and perform necessary maintenance; batteries were replaced every other day.

\section{Nest Predators in Pastures}

We studied nest predators in continuously grazed pastures in southwestern Wisconsin in 20002001 located primarily within Iowa, Lafayette, and Green counties. Specifically, the pastures used were a subset of pastures used by Renfrew and Ribic (2003) in their study of nest predators, 1999-2000. We used ten pastures during the study (mean patch size $=39.5$ ha, $\mathrm{SD}=39.9$; range $=$ 11.7-142.7; mean vegetation height-density $=$ $1.1 \mathrm{dm}, \mathrm{SD}=0.3$ ). Pastures were dominated by nonnative cool-season grasses such as Kentucky bluegrass and brome (Bromus spp.). Pastures were used to graze beef cattle; average stocking rate in May-July was 2.1 Animal Units/ha (SD $=1.0$, $n=9$; range $=0.80-4.31$ ). Methods for finding, marking, placing cameras, and monitoring nests in the pastures followed the protocols described above; video recording devices were protected from cattle with a pyramid constructed from metal hog fencing.

\section{Predator Activity}

To sample activity rates of potential and known nest predators, we used sand track stations along woody and non-woody edges in CRP $(n=8)$, prairie $(n=5)$, and pasture $(n=5)$. We used a paired design (set of four stations per edge) to sample an equal amount of woody and non-woody edge on an individual site. We followed the protocol of Renfrew et al. (2005). Within a set, track stations were placed $30 \mathrm{~m}$ apart and no track stations were placed within $50 \mathrm{~m}$ of a change in edge type. Interior track stations (four stations at least $100 \mathrm{~m}$ from the nearest edge and closest to the center of the field) were placed on six CRP sites in 2003 and 2004. We did not place interior track stations at prairie sites due to concern over disturbance to 
native plants, or at pasture sites because cattle disturbed the stations.

A track station consisted of a $1-\mathrm{m}^{2}$ plot with the sod layer removed, a mixture of fine sand and mineral oil spread over the plot, and a white unscented predator survey disk $(3.5 \mathrm{~cm})$ as a novelty item (Renfrew et al. 2005). Due to concern for native plant species on prairie sites, sod was not removed but vegetation was clipped using hand-held garden shears and sand was leveled on top. We controlled vegetation encroaching onto the track stations by trimming the vegetation throughout the summer. We checked track stations every other day to allow time for predator response and to minimize weather disturbance. Monitoring occurred by two technicians wearing rubber boots, and care was taken to not create paths to and from the stations. We recorded date, time, species present, track measurements, and weather information for each sampling period. Technicians used field guides (Elbroch 2003, Murie and Elbroch 2005) to identify species; if there was a question about a track, measurements were taken along with a digital photo for identification by Wisconsin Department of Natural Resources researchers.

\section{Data Analysis}

We focused on obligate grassland bird species; these species require grasslands for all parts of their breeding cycle and are of management concern in the state of Wisconsin (Sample and Mossman 1997).

\section{Vegetation and Patch Variables}

Within six days of fledging or failure at each nest, we measured vegetation height-density, averaging four height-density measurements $(\mathrm{dm})$, one in each cardinal direction, using a modified Robel pole (Robel et al. 1970). The Robel pole was read from a height of $1.5 \mathrm{~m}$ at a distance of $4 \mathrm{~m}$. Ocular estimates of ground cover (proportion litter, proportion forb, and proportion grass) were made using a $50 \times 20 \mathrm{~cm}$ frame. Litter depth $(\mathrm{cm})$ was an average of three measurements made within the frame. These variables had correlations of less than 0.50 .

We measured the following patch characteristics for each nest: estimated density of the bird species in the patch (birds/ha based on line transects; see Ribic et al. 2009a), patch area (ha) on the log-scale, distance to nearest edge $(\mathrm{m})$, distance to nearest woody edge $(\mathrm{m})$, and topographical location. To measure distances, we defined an edge as the boundary between the patch and a different land use. Edge type was designated as woody (trees and/or shrubs where a tree is woody vegetation more than $3 \mathrm{~m}$ tall) or non-woody (any noticeable change in vegetation structure or land use). We measured distances ( $\mathrm{m}$ ) from the nest to the nearest edge and nearest woody edge using ArcView GIS (Environmental Systems Research Institute 1996). We categorized topographical location as ridgetop, midslope, or valley.

\section{Nest Survival}

We used the logistic exposure method (Shaffer 2004) to estimate daily survival for each obligate grassland bird species regardless of number of nests (i.e., we fit the constant survival model). We then used the predicted daily survival rate exponentiated to the length of the nesting period for each species to calculate the probability of fledging young per nest attempt. We used a 23-day nesting period (incubation and nestling period combined) for Bobolinks (Dolichonyx oryzivorus) (Martin and Gavin 1995) and 21-day nesting period for Henslow's Sparrow (Ammodramus henslowii) (Herkert et al. 2002). From our data, nesting period for Eastern Meadowlark (Sturnella magna) was 24 days, 19 days for Grasshopper Sparrow (A. savannarum), 25 days for Upland Sandpiper (Bartramia longicauda), and 21 days for Savannah Sparrow (Passerculus sandwichensis).

We then analyzed nesting success in relation to nest vegetation variables and patch characteristics for Grasshopper Sparrow and Eastern Meadowlark, the only two obligate grassland species with at least 50 nests found over the years of study. We modeled within-patch relationships first and then determined the importance of patch-level characteristics following the approach of Renfrew and Ribic (2008). In the first analysis, we modeled nesting success as a function of nest vegetation variables (described above), nesting stage, year, and site. The a priori models were the combinatoric set of explanatory variables taken $n$ at a time; specific interactions modeled were vegetation variables by year. We also considered models using habitat type as a substitute for the vegetation variables following Ribic and Sample 
(2001). We then modeled the importance of patch characteristics using the best nest vegetation model as the base model; the patch characteristics (described above) were added in combinatoric sets of $n$ at a time; distance to nearest edge and distance to nearest woody edge were in separate models. We also included the models of patch characteristics independently of the nest vegetation variables. We considered the importance of patch characteristics using the nest vegetation model within 2 AIC units of the minimum AIC nest vegetation model as well. The second-best nest vegetation models were always the minimum AIC nest vegetation model with additional variables. Results of the patch characteristics analyses were the same, and we only report the analyses using the minimum AIC nest vegetation model. Using the minAIC model from the model set including patch characteristics, we plotted daily survival rate predicted for different values of each explanatory variable to determine the effect of the vegetation or patch variable on daily survival rate; the other explanatory variables were fixed at the sample means.

We used $\mathrm{AIC}_{\mathrm{c}}$ to rank the models (Burnham and Anderson 2002). We used the model with the minimum $\mathrm{AIC}_{c}$ from the nest vegetation analysis as the base model for assessing the importance of the patch-based variables. We calculated $\mathrm{AIC}_{c}$ weights to assess the importance of the different models (Burnham and Anderson 2002). Analyses were done using $\mathrm{R}$ (ver. 2.9.0, R Foundation for Statistical Computing, Vienna, Austria).

\section{Nest Predators}

We identified species from the tapes with the help of researchers from the Wisconsin Department of Natural Resources. For larger species, clues such as color and length of nails, fur color and definition, and dexterity were used to determine species identity. Species depredating nests were classified to class and then to genus or species level (i.e., the lowest level possible). If a nest was depredated on different days, those events were counted as separate events; we could not identify individual predators. Eye-witnessed predation events were included, but predator species only identified by sign left at the nest were not included, following Renfrew and Ribic (2003). Our list of predators was then combined with data from Renfrew and Ribic (2003) to produce a table of nest predators in continuously grazed pastures from 1999 to 2001 .
We then assigned all species to either a grassland or a woodland habitat association using information from Patischniak-Arts and Messier (1995), Igl and Johnson (1997), Lariviere and Messier (1998), Christoffel et al. (2000), Renfrew and Ribic (2003), Phillips et al. (2003, 2004), and Renfrew et al. (2005). For each habitat type, we calculated proportion of predation events by class, by habitat association, and by species within a habitat association.

Distances of depredated and successful nests with cameras to nearest edge and edge type (wooded or non-wooded) were measured as explained in the nest survival analysis section (above). We tested for differences between distance to edge for nests depredated by predator habitat association groups and successful nests. Within depredated nests, we tested for differences between distances to woody edge for specific predator species. We used general linear models with a Gaussian error structure and assessed significance at 0.05 . Analyses were done using R (ver. 2.9.0, R Foundation for Statistical Computing, Vienna, Austria).

\section{Predator Activity}

Because tracks are unreliable in distinguishing between individuals of a species, tracks counted at each station were considered one visit for that species (Heske et al. 1999). We used visitation rates (visits/station/day) for species documented on the track stations as an index to predator activity. We found five known nest predators-raccoon, whitetailed deer (Odocoileus virginianus), coyote (Canis latrans), American badger (Taxidea taxus), and thirteen-lined ground squirrel—at all sites and focused our analysis on them.

For each species, we averaged visitation rates over the years for each site and by edge type. We tested for differences among habitats and between edge types by species using a linear model with a Gaussian error structure. To test for differences between activity at interior and edge stations in CRP fields by species, we used a paired- $t$ test. For all tests, significance was assessed at $P \leq 0.05$. Analyses were done using R (ver. 2.9.0, R Foundation for Statistical Computing, Vienna, Austria).

\section{RESULTS \\ Nesting Activity}

There were 212 nests of obligate grassland bird species found during the study; 87 nests were 
found on remnant prairie, 61 nests on CRP fields, and 64 on pastures. The majority of nests found were Eastern Meadowlark (86 nests) and Grasshopper Sparrow (73 nests), followed by Bobolink (20 nests).

Eastern Meadowlark nests were found in all three habitat types (31 in CRP fields, 28 in pastures, and 27 in remnant prairies). Grasshopper Sparrow nests were primarily found in remnant prairie (49 nests) and pastures (20 nests); only four nests were found in CRP fields. Bobolink nests were primarily found in CRP fields (14 nests) with few found in pastures (4 nests) and remnant prairie (2 nests). Henslow's Sparrow nests were found only in CRP fields (11 nests), while Savannah Sparrow nests were found in pastures (10 of 11 nests; a single nest found in remnant prairie). Upland Sandpiper nests were primarily found in remnant prairie (8 of 9 nests; single nest found in a CRP field). A single nest each of Western Meadowlark (Sturnella neglecta) and Vesper Sparrow (Pooecetes gramineus) was found in pasture.

Estimated daily nest survival rate (DSR) was 0.9404 for Eastern Meadowlarks $(\mathrm{SE}=0.1466)$,
0.9321 for Grasshopper Sparrows $(\mathrm{SE}=0.1569$ ), 0.9418 ( $\mathrm{SE}=0.2848$ ) for Bobolinks, 0.9561 $(\mathrm{SE}=0.4627)$ for Henslow's Sparrows, 0.9737 $(\mathrm{SE}=0.5904)$ for Upland Sandpipers, and 0.9308 $(\mathrm{SE}=0.3685)$ for Savannah Sparrows. Overall, Eastern Meadowlarks had a 23\% chance of fledging young per nest attempt (95\% CI: 14\%-33\%), Grasshopper Sparrows had a 26\% chance $(95 \%$ CI: $17 \%-37 \%$ ) and Bobolinks had a $25 \%$ chance (95\% CI: 9\%-45\%). Henslow's Sparrow had a 39\% chance (95\% CI: 10\%-68\%), Upland Sandpipers had a $51 \%$ chance (95\% CI: $13 \%-81 \%)$, and Savannah Sparrows had a $22 \%$ chance of fledging young per nest attempt (95\% CI: $5 \%-47 \%$ ); the wide confidence intervals for these species are due to the low numbers of nests found.

For Eastern Meadowlark, the nest survival model with the minimum $\mathrm{AIC}_{\mathrm{c}}$ value was nesting stage, regardless of the set of models considered (Table 10.1). There were five models within 2 AIC units of the minAIC model; all were composed of nesting stage with different variables, and none of these additional variables were significant ( $P>0.25$, all terms). The nesting stage model was 70 times more likely to be the

TABLE 10.1

Models with more support than the constant survival model for Eastern Meadowlark nests found on sites in southwest Wisconsin, May-July 2002-2004.

\begin{tabular}{|c|c|c|c|c|}
\hline Model & K & Dev & $\Delta \mathrm{AIC}_{\mathrm{c}}$ & $w_{i}$ \\
\hline Nest stage & 2 & 295.68 & 0 & 0.247 \\
\hline Nest stage + distance to nearest edge & 3 & 296.70 & 1.03 & 0.148 \\
\hline Nest stage + bird density & 3 & 297.28 & 1.61 & 0.111 \\
\hline Nest stage + distance to nearest woody edge & 3 & 297.30 & 1.63 & 0.109 \\
\hline Nest stage $+\log ($ patch area $)$ & 3 & 297.68 & 2.00 & 0.090 \\
\hline Nest Stage + nest location & 4 & 298.58 & 2.93 & 0.057 \\
\hline Nest stage $+\log ($ patch area $)+$ distance to nearest edge & 4 & 298.63 & 2.98 & 0.056 \\
\hline Nest stage + distance to nearest edge + nest location & 5 & 298.74 & 3.11 & 0.052 \\
\hline Nest stage $+\log ($ patch area $)+$ distance to nearest woody edge & 4 & 299.30 & 3.65 & 0.040 \\
\hline Nest stage + distance to nearest woody edge + nest location & 5 & 300.22 & 4.59 & 0.025 \\
\hline Nest stage $+\log ($ patch area $)+$ nest location & 5 & 300.53 & 4.91 & 0.021 \\
\hline Nest stage $+\log ($ patch area $)+$ distance to nearest edge + nest location & 6 & 300.67 & 5.08 & 0.019 \\
\hline Nest stage $+\log ($ patch area $)+$ distance to nearest woody edge + nest location & 6 & 302.19 & 6.60 & 0.009 \\
\hline Constant & 1 & 304.18 & 8.48 & 0.003 \\
\hline
\end{tabular}

NOTE: $n=804$ exposure days. 


\begin{tabular}{|c|c|c|c|c|}
\hline Model & K & Dev & $\Delta \mathrm{AIC}_{\mathrm{c}}$ & $w_{i}$ \\
\hline $\begin{array}{l}\text { Distance to nearest woody edge }+ \text { proportion forb } \\
\text { at nest }+ \text { proportion litter at nest }\end{array}$ & 4 & 229.90 & 0 & 0.387 \\
\hline $\begin{array}{l}\text { Distance to nearest woody edge }+ \text { proportion forb } \\
\text { at nest }+ \text { proportion litter at nest }+ \text { bird density }\end{array}$ & 5 & 231.03 & 1.17 & 0.216 \\
\hline $\begin{array}{l}\text { Distance to nearest woody edge }+ \text { nest location }+ \\
\text { proportion forb at nest }+ \text { proportion litter at nest }\end{array}$ & 5 & 231.82 & 1.96 & 0.145 \\
\hline $\begin{array}{l}\log (\text { patch area })+\text { distance to nearest woody edge }+ \\
\text { nest location }+ \text { proportion forb at nest }+ \text { proportion litter at nest }\end{array}$ & 6 & 233.52 & 3.69 & 0.061 \\
\hline Proportion forb at nest + proportion litter at nest & 3 & 233.62 & 3.70 & 0.060 \\
\hline Proportion forb at nest + proportion litter at nest + bird density & 4 & 234.02 & 4.12 & 0.049 \\
\hline $\log ($ patch area $)+$ proportion forb at nest + proportion litter at nest & 4 & 235.16 & 5.26 & 0.028 \\
\hline Distance to nearest edge + proportion forb at nest + proportion litter at nest & 4 & 235.43 & 5.53 & 0.024 \\
\hline Nest location + proportion forb at nest + proportion litter at nest & 4 & 235.62 & 5.72 & 0.022 \\
\hline $\log ($ patch area) & 2 & 240.00 & 10.05 & 0.002 \\
\hline Distance to nearest edge & 2 & 243.20 & 13.26 & 0.0005 \\
\hline Constant survival & 1 & 243.73 & 13.77 & 0.0003 \\
\hline
\end{tabular}

NOTE: $n=613$ exposure days.

best model than the constant survival model. Specifically, DSR during incubation was 0.9073 (95\% CI: 0.8713-0.9341), while DSR during the nestling period was higher at $0.9622(95 \% \mathrm{CI}$ : $0.9338-0.9787)$. Using 12 days for each period (based on our data) results in a $19.6 \%$ overall chance of fledging young per nest attempt $(95 \%$ CI: $8.4 \%-34.1 \%)$; this lower chance of fledging young compared to that based on constant survival is due to the low probability of successfully completing incubation.

For Grasshopper Sparrow, the minAIC $\mathrm{C}_{\mathrm{c}}$ model from the nest vegetation analysis was a combination of proportion forb and litter. When patch characteristics were considered, the $\operatorname{minAIC}_{c}$ model was composed of this base vegetation model and distance to the nearest woody edge (Table 10.2). The minAIC $_{c}$ vegetation-patch model was about 1,500 times more likely to be the best model than the constant survival model and was 6 times more likely to be the best model compared to the base nest vegetation model. Other vegetation-patch models within 2 units of the minAIC ${ }_{c}$ model were the minAIC ${ }_{c}$ model with additional patch-level variables; these additional patch-level variables were not significant $(P>0.25)$. Using the minAIC $\mathrm{C}_{\mathrm{c}}$ model, predicted DSR for Grasshopper Sparrow nests declined as proportion of litter or forb at the nest increased (Fig. 10.1a-b). DSR declined as nests were placed farther away from tree rows (Fig. 10.1c). Specifically, when proportion of litter at the nest was low $(0.20$ with proportion forb at nest $=0.14$, distance from woody edge $=100 \mathrm{~m}$ ), there was a $44 \%$ chance of young fledging per nest attempt; when proportion of litter at the nest was high (1.0), there was a $41 \%$ chance of young fledging. Looking at proportion of forb at the nest (proportion litter $=0.87$, distance to tree row $=100 \mathrm{~m}$ ), a lower proportion of forb (0.15) resulted in a $42 \%$ chance of young fledging per nest attempt, while a higher proportion of forb (0.35) reduced that chance to $36 \%$. Considering distance to woody edge (proportion forb $=0.14$, proportion litter $=$ $0.87)$, nests nearer a woody edge $(15 \mathrm{~m})$ had a $43 \%$ chance of fledging young per nest attempt, while nests in the center of the field $(293 \mathrm{~m})$ had a $39 \%$ chance. 

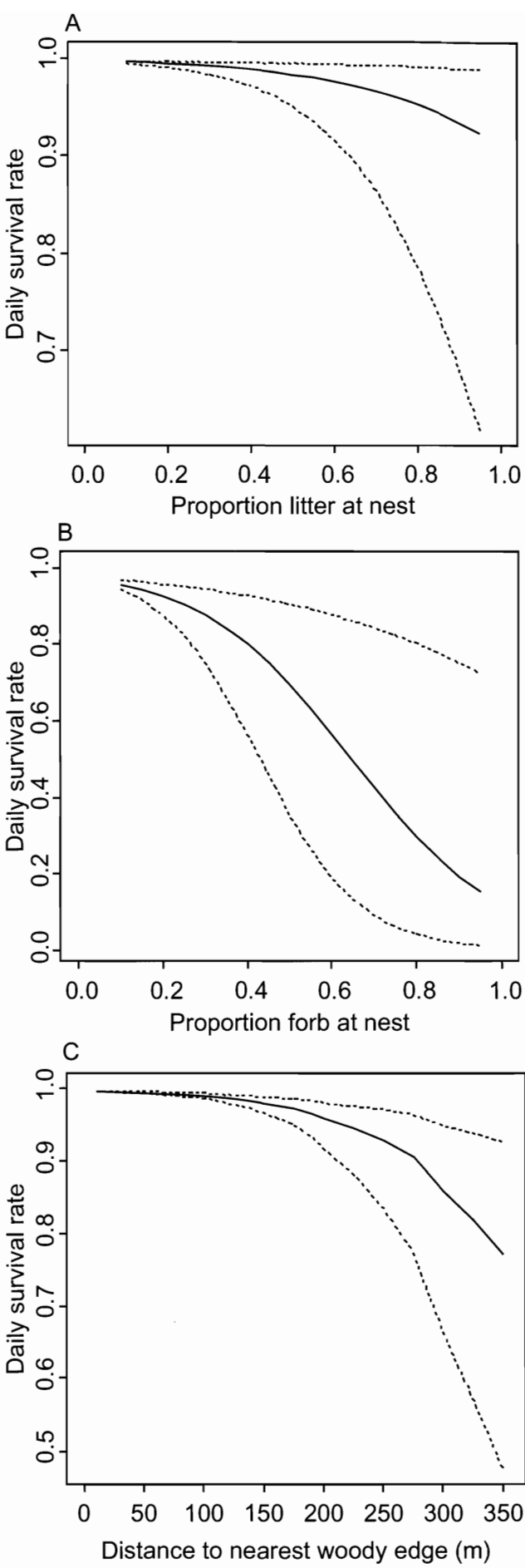

Figure 10.1. Estimated daily nest survival (DSR) for Grasshopper Sparrows as a function of (a) proportion of litter at the nest, (b) proportion of forbs at the nest, and (c) distance to the nearest woody edge for nests found on study sites in southwest Wisconsin, May-July 2002-2004. There were 23 nests within $50 \mathrm{~m}$ of a woody edge, 21 between 50 and $100 \mathrm{~m}$, and 29 beyond $100 \mathrm{~m}$.

\section{Nest Predators}

In CRP fields and remnant prairies, 46 nests of obligate grassland bird species were monitored with cameras; 39 in CRP fields and 7 in remnant prairie. Twenty-four predation events were recorded; the predator identities for two events (one in prairie and one in CRP) were unknown due to malfunctioning equipment. There were three nest predations in remnant prairie; one nest was depredated by American badger and another was depredated twice by thirteen-lined ground squirrels. In pastures, 127 nests of obligate grassland bird species were monitored with cameras. Fifty-one predation events were recorded; the predator identities for six events were unknown due to malfunctioning equipment. In addition, cattle destroyed 11 nests by trampling, sitting on the nest, or knocking the camera onto the nest.

The majority of all nest predators were mammals, regardless of habitat (CRP/remnant prairie: $91 \%$; pasture: $78 \%$ ) (Table 10.3). In CRP fields and remnant prairie, $73 \%$ of the predators were associated with grasslands and $27 \%$ with woody habitats. Of the grassland-associated predators in those habitats, $44 \%$ were thirteen-lined ground squirrels (Table 10.3). Though no snakes were recorded depredating nests in the CRP fields and remnant prairies in 2002-2004, a 2001 pilot study on one of the CRP fields used in this study documented a multiple snake nest predation event [common gartersnake (Thamnophis sirtalis) and milksnake (Lampropeltis triangulum)]. In pastures, 33\% of the predators were associated with grasslands and $56 \%$ with woody habitats. Of the grasslandassociated predators, $40 \%$ were thirteen-lined ground squirrels. Of the woody-habitat associated predators, $60 \%$ were raccoons. Snakes depredated nests in pastures at a relatively low frequency (Table 10.3). Considering domestic animals, cattle were recorded depredating nests in pastures; cats were also recorded depredating nests in pastures, though at relatively low frequencies (Table 10.3).

For the camera nests, average distance to a woody edge of a nest depredated by a woodland-associated predator was $76.7 \mathrm{~m}(\mathrm{SD}=23.8, n$ $=6), 152.8 \mathrm{~m}(\mathrm{SD}=117.4, n=15)$ for nests depredated by a grassland-associated predator, and $104.8 \mathrm{~m}(\mathrm{SD}=59.8, n=15)$ for successful 
TABLE 10.3

Species captured on video depredating or partially depredating grassland bird nests, May-July on Conservation Reserve Program (CRP) fields, remnant prairie sites, and continuously grazed pastures in southwest Wisconsin.

\begin{tabular}{|c|c|c|c|c|}
\hline \multirow[b]{2}{*}{ Species } & \multirow[b]{2}{*}{ Class } & \multirow[b]{2}{*}{$\begin{array}{l}\text { Habitat } \\
\text { association }\end{array}$} & \multicolumn{2}{|c|}{ Predation events } \\
\hline & & & $\begin{array}{l}\text { CRP fields/ } \\
\text { remnant prairie }\end{array}$ & Pasture \\
\hline $\begin{array}{l}\text { Thirteen-lined ground squirrel } \\
\text { (Ictidomys tridecemlineatus) }\end{array}$ & Mammalia & Grassland & 7 & 6 \\
\hline Coyote/dog (Canis spp.) & Mammalia & Grassland & 3 & 2 \\
\hline Fox (Vulpes spp.) & Mammalia & Grassland & 0 & 1 \\
\hline $\begin{array}{l}\text { Striped skunk } \\
\text { (Mephitis mephitis) }\end{array}$ & Mammalia & $\begin{array}{l}\text { Grassland, } \\
\text { Wetland }\end{array}$ & 1 & 3 \\
\hline $\begin{array}{l}\text { American badger } \\
\text { (Taxidea taxus) }\end{array}$ & Mammalia & Grassland & 1 & 2 \\
\hline Voles (Microtus spp.) & Mammalia & Grassland & 2 & 0 \\
\hline Weasels (Mustela spp.) & Mammalia & Grassland & 2 & 0 \\
\hline Raccoon (Procyon lotor) & Mammalia & Woody & 3 & 15 \\
\hline Raptor (Buteo spp.) & Aves & Woody & 2 & 3 \\
\hline $\begin{array}{l}\text { Virginia opossum } \\
\text { (Didelphis virginiana) }\end{array}$ & Mammalia & Woody & 1 & 1 \\
\hline $\begin{array}{l}\text { Brown-headed cowbird } \\
\text { (Molothrus ater) }\end{array}$ & Aves & Woody & 0 & 3 \\
\hline $\begin{array}{l}\text { Common gartersnake } \\
\text { (Thamnophis sirtalis) }\end{array}$ & Reptilia & Woody, Wetland & 0 & 3 \\
\hline $\begin{array}{l}\text { Western foxsnake } \\
\text { (Mintonius vulpinus) }\end{array}$ & Reptilia & $\begin{array}{l}\text { Grassland, } \\
\text { Wetland }\end{array}$ & 0 & 1 \\
\hline Cat (Felis catus) & Mammalia & Domestic & 0 & 2 \\
\hline Cow (Bos taurus) & Mammalia & Domestic & 0 & 3 \\
\hline
\end{tabular}

NOTES: Data were collected in 2002-2004 on CRP fields and remnant prairie sites and 1999-2001 on continuously grazed pastures. Common and scientific names for reptiles are taken from Crother (2008). For the three coyote/dog events in CRP fields/remnant prairie, two were coyotes (Canis latrans), but the other was most likely a domestic dog (Canis lupis familiaris).

nests; these distances were not significantly different $\left(F_{2,33}=2.07, P=0.46\right)$. Woodlandassociated predators were recorded at nests as far as $118 \mathrm{~m}$ into the fields and grassland-associated predators depredated nests within $29 \mathrm{~m}$ of an edge (mean $=71.7 \mathrm{~m}, \mathrm{SD}=52.1, n=15$ ). However, within the grassland-associated predators, thirteen-lined ground squirrels depredated nests farther away from a woody edge than did the other grassland-associated predators $\left(F_{1,13}\right.$ $=8.03, P=0.01)$. Nests depredated by thirteenlined ground squirrels were on average $227.7 \mathrm{~m}$ from a woody edge ( $\mathrm{SD}=108, n=7$ ) compared to $87.2 \mathrm{~m}$ ( $\mathrm{SD}=83.9, n=8)$ for nests depredated by the other grassland-associated predators.

\section{Predator Activity}

Mean effort for track stations was 20.9 days (range $=19-28), 45.5$ days (range $=44-48)$, and 42.4 days (range $=35-48$ ) in 2002, 2003, and 2004, respectively. Raccoon and deer showed differences in activity along the edges of the three habitats $(P<0.05$, both tests). Raccoon visitation rates were highest around pastures and lowest around prairies (Table 10.4); regardless of habitat, 
TABLE 10.4

Mean visitation rates (visits/station/day) (SE) by species and habitat collected with track stations (pooled for woody and non-woody edge types) on three grassland habitats in southwest Wisconsin, May-July 2002-2004.

\begin{tabular}{llll}
\hline & & \multicolumn{3}{c}{ Habitat } \\
\cline { 2 - 4 } Species & $\begin{array}{c}\text { CRP Fields } \\
(n=8)\end{array}$ & $\begin{array}{c}\text { Pasture } \\
(n=5)\end{array}$ & $\begin{array}{c}\text { Prairie } \\
(n=5)\end{array}$ \\
\hline $\begin{array}{l}\text { Raccoon } \\
\text { White-tailed deer }\end{array}$ & $0.060^{\mathrm{a}, \mathrm{b}}(0.013)$ & $0.093^{\mathrm{b}}(0.020)$ & $0.028^{\mathrm{a}}(0.006)$ \\
$\begin{array}{l}\text { Odocoileus virginianus) } \\
\text { Coyote }\end{array}$ & $0.115^{\mathrm{a}}(0.016)$ & $0.028^{\mathrm{b}}(0.014)$ & $0.084^{\mathrm{a}, \mathrm{b}}(0.021)$ \\
American badger & $0.013(0.003)$ & $0.016(0.003)$ & $0.017(0.008)$ \\
Thirteen-lined ground squirrel & $0.003(0.001)$ & $0.005(0.003)$ & $0.012(0.004)$ \\
& $0.019^{\mathrm{a}, \mathrm{b}}(0.004)$ & $0.008^{\mathrm{a}}(0.004)$ & $0.031^{\mathrm{b}}(0.004)$
\end{tabular}

NOTES: CRP $=$ Conservation Reserve Program. Within a row, means with different letters are significantly different from each other at $P \leq 0.05$. Rows with means with no letters are not significantly different from each other.

TABLE 10.5

Mean visitation rates (visits/station/day) (SE) by species and track station location (interior/edge) collected on six Conservation Reserve Program fields in southwest Wisconsin, May-July 2003-2004.

\begin{tabular}{llc}
\hline \multirow{2}{*}{ Species } & \multicolumn{2}{c}{ Track station location } \\
\cline { 2 - 3 } Raccoon & \multicolumn{1}{c}{ Interior } & \multicolumn{1}{c}{ Edge } \\
Coyote & $0.007^{\mathrm{a}}(0.002)$ & $0.048^{\mathrm{b}}(0.011)$ \\
Thirteen-lined ground squirrel & $0.019^{\mathrm{a}}(0.006)$ & $0.011^{\mathrm{a}}(0.002)$ \\
White-tailed deer & $0.043^{\mathrm{a}}(0.010)$ & $0.016^{\mathrm{b}}(0.004)$ \\
American badger & $0.033^{\mathrm{a}}(0.006)$ & $0.073^{\mathrm{b}}(0.014)$ \\
& $0.005^{\mathrm{b}}(0.002)$ & $0.001^{\mathrm{b}}(0.0004)$ \\
\hline
\end{tabular}

NOTE: Within a row, means with different letters are significantly different from each other at $\mathrm{P} \leq 0.05$.

raccoon were more active along the woody edge (mean visitation rate $=0.059$ visits $/$ station $/$ day, $\mathrm{SD}=0.030)$ compared to the non-woody edge (mean visitation rate $=0.038, \mathrm{SD}=0.043)\left(t_{17}=\right.$ 3.7, $P=0.002)$. Deer, in contrast, had higher visitation rates around CRP fields and lowest around pastures (Table 10.4). Both raccoon and deer were about twice as active along the woody edges compared to the non-woody edges $(P<0.001$, both tests). Coyote and badger did not show any differences in edge activity among habitats $(P>0.10$, both tests) or by edge type ( $P>0.25$, both tests). Thirteen-lined ground squirrels were more active on the edges of prairies compared to pastures $\left(F_{2,15}=6.8, P=0.008\right)$ (Table 10.4); they were also five times more active along the non-woody edges (mean visitation rate $=0.025$ visits $/$ station/ day, $\mathrm{SD}=0.022$ ) compared to the woody edges (mean visitation rate $=0.006, \mathrm{SD}=0.008)\left(t_{17}=\right.$ 3.68, $P=0.002$ ).

Raccoon and deer, the two woodland-associated species, were about five times more active around the edges of CRP fields compared to the interior $(P<0.01$, both tests) (Table 10.5). Coyote and badger, two grassland-associated species, did not differ in their visitation rates between interior and edge stations at CRP fields $(P>0.10$, both tests $)$ (Table 10.5). In contrast, thirteen-lined ground squirrel, another grassland-associated species, was about four times more active along interior stations compared to CRP field edges $\left(t_{5}=3.0\right.$, $P=0.03$ ) (Table 10.5). 


\section{DISCUSSION}

In an agricultural landscape in Wisconsin with a relatively high proportion of grassland compared to the state as a whole, grassland bird species nested in different grassland habitats, consistent with species-specific habitat requirements. In our study, Bobolinks and Henslow's Sparrows primarily nested in CRP fields, the habitat type with the tallest and densest vegetation, a known characteristic of habitat suitable for these species (Dechant et al. 2003c, Herkert 2003). Savannah Sparrows nested in the habitat with the lowest vegetation-height density (pasture), although the actual nest sites were typically in tufts or small patches of higher vegetation. Grasshopper Sparrows and Upland Sandpipers nested primarily in the habitat with the sparsest, most open vegetation structure (prairie), consistent with these species' habitat requirements (Sample 1989; Dechant et al. 2003a, 2003b; Swanson 2003). Both Upland Sandpiper and Grasshopper Sparrow nested almost exclusively in the shortgrass native vegetation found on the remnant prairie sod within the prairie sites. It was not surprising that Eastern Meadowlark nested in all three habitats, as that species is a habitat generalist that nests in a wide variety of grassland habitats (Sample 1989, Hull 2003).

Habitat type per se was not a factor that was important in explaining variation in daily nest survival rate. There are few studies that have tried to compare some aspect of grassland bird productivity across habitat types. Grassland bird nesting success did not appear to vary between warm- and cool-season CRP plantings (Henningsen and Best 2005, Fletcher et al. 2006), while Patterson and Best (1996) noted that nesting success of Grasshopper Sparrows in CRP fields was twice that in hayfields (citing Frawley 1989). The estimates of daily nest survival and probability of fledging at least one chick per nest attempt for the different species in our study are similar to those reported by others in a variety of habitats and geographic areas (Patterson and Best 1996, Koford 1999, Winter et al. 2000, Herkert et al. 2002, Davis 2003, Galligan et al. 2006, Perkins and Vickery 2007, Giocomo et al. 2008, Walk et al. 2010).

We are just beginning to identify nest predators using miniature camera technology in different systems and habitats (Thompson and Burhans 2003, Pietz et al., chapter 1 , this volume, Reidy and Thompson, chapter 11, this volume), making it difficult to compare and generalize across systems and habitats. In our study, regardless of habitat type, mammals were the dominant predator; this is similar to that found in the grasslands of North Dakota but is different from that found in Iowa/Nebraska, where mammals and snakes were the important nest predators (Pietz et al., chapter 1 , this volume). However, when we look closer at the general habitat preferences of the nest predators, additional patterns emerge. In our study, we found that the habitat associations of the nest predator community are different between pastures (woody habitat and grassland associated) and CRP fields (grassland associated). The dominant species of nest predator also varied between pastures (raccoons and thirteen-lined ground squirrels) and CRP fields (thirteen-lined ground squirrels). Snakes were not an important nest predator in our study compared to other studies (Thompson and Burhans 2003, Pietz et al., chapter 1 , this volume) but the species that were found varied in their habitat associations. The grassland-associated snake species we found depredating nests are likely using old farmsteads and outbuildings with stone foundations (Christoffel et al. 2000), as well as piles of rocks picked from fields, as hibernacula; this suggests to us that the importance of grassland-associated snake species as nest predators is likely dependent on the distribution of suitable hibernacula sites in the agricultural landscape of southwest Wisconsin and as a consequence will be patchy or field-specific. All this indicates that while some generalities may be likely, understanding the ecology and distribution patterns of the specific nest predator is going to be important in order to understand mechanisms of predation (Lahti 2009, Thompson and Ribic, chapter 2, this volume).

In our study, Grasshopper Sparrow nests had higher daily survival when the nests were closer to a woody edge and also when nests were placed in areas with relatively low ground cover. These patterns are indicative of the pressure of grasslandassociated nest predators; in our study, thirteenlined ground squirrels avoided woody edges, had higher activity and higher predation on nests in the center of the fields, and are likely using higher ground cover for protection from their own predators. Other studies, though not studying nest predators directly, have implicated grasslandassociated predators as factors affecting grassland 
bird nesting success (e.g., Davis 2003, Skagen et al. 2005, Grant et al. 2006). Grant et al. (2006) postulated that Vesper Sparrow had better nesting success on the woody edges of their study fields because of the presence of thirteen-lined ground squirrels in the middle of their study sites.

Vegetation structure may play some role in affecting movement of woodland-associated or edge predators into grassland habitats (Pasitschniak-Arts and Messier 1995), but information is lacking for most predators (Ribic et al. 2009b). In pastures with low vegetation heightdensity, raccoons moved throughout the pastures (Renfrew et al. 2005). In contrast, in our CRP fields which had significantly higher vegetation height-density values, there was little evidence of raccoons moving into the field centers. Whether nesting success is affected by nest placement near woody edges (e.g., Winter et al. 2000, Bollinger and Gavin 2004) or not (e.g., Renfrew et al. 2005) likely depends on the species composition, abundance, and activity of grassland-associated predators compared with woody-edge predators, which in turn depends on the interplay of variables we as yet poorly understand (e.g., arrangement of habitat features, range and variation of prey base, disease outbreaks, and competition among predators) (Lahti 2001, Chalfoun et al. 2002, Stephens et al. 2003, Ribic et al. 2009b).

From both population size and productivity perspectives, when managing for grassland birds across a single agricultural landscape with a large amount of grassland, a continuum or diversity of habitat types will be needed if our goal is to conserve a diverse community of grassland birds there (Ryan 1986, Madden et al. 2000, Ribic et al. 2009a). From a practical perspective, the larger the landscape, the larger the diversity of habitats managed for can be. However, understanding other aspects of the grassland system is becoming important if we are to increase the likelihood that our conservation plans will be effective for maintaining sustainable populations of birds over the long term.

Using video camera technology to identify nest predators was indispensable in furthering our understanding of the grassland system. Now one of the main challenges is using that additional knowledge to develop management actions for both the bird and predator communities (Lahti 2001, Chalfoun et al. 2002, Thompson and Ribic, chapter 2, this volume). For example, Winter et al. (2000) advocated large-scale removal of woody vegetation to reduce populations of midsized mammals, the presumed grassland bird nest predators in their system. In our system, such an approach may not be effective because the major predators in our study are associated with the grassland habitats being managed. Though understanding the entire system (e.g., vegetation structure, edge characteristics, bird and predator communities) brings additional complexities, taking a systems approach would be helpful in designing more effective management strategies to help conserve grassland birds (Whittingham and Evans 2004).

\section{ACKNOWLEDGMENTS}

We are grateful for the assistance provided by field technicians and colleagues, especially J. Dadisman, throughout the duration of these studies. We are very grateful for the support of cooperating landowners. We thank K. Bakker, R. Koford, and two anonymous reviewers for their comments on earlier versions of the manuscript. Mention of trade names or commercial products does not constitute endorsement for use by the U.S. government. Funding was provided by the U.S. Department of Agriculture Hatch Grant Program, U.S. Fish and Wildlife Service Regional Nongame Bird Conservation Program and Partnerships for Wildlife Program, Wisconsin Department of Natural Resources under Federal Aid in Wildlife Restoration Project W-160-P, and U.S. Geological Survey Wisconsin Cooperative Wildlife Research Unit. We thank the Department of Forest and Wildlife Ecology, University of Wisconsin, Madison, for assistance with publication expenses.

\section{LITERATURE CITED}

Askins, R. A., F. Chavez-Ramirez, B. C. Dale, C. A. Haas, J. R. Herkert, F. L. Knopf, and P. D. Vickery. 2007. Conservation of grassland birds in North America: understanding ecological processes in different regions. Ornithological Monographs No. 64.

Bollinger, E. K., and T. A. Gavin. 2004. Responses of nesting Bobolinks (Dolichonyx oryzivorus) to habitat edges. Auk 121:767-776.

Brennan, L. A., and W. P. Kuvlesky, Jr. 2005. North American grassland birds: an unfolding conservation crisis? Journal of Wildlife Management 69:1-13.

Burnham, K. P., and D. R. Anderson. 2002. Model selection and multimodel inference: a practical information-theoretic approach. Second edition. Springer-Verlag, New York, NY. 
Chalfoun, A. D., F. R. Thompson III, and M. J. Ratnaswamy. 2002. Nest predators and fragmentation: a review and meta-analysis. Conservation Biology 16:306-318.

Christoffel, R., R. Hay, and L. Ramirez. 2000. Snakes of Wisconsin. PUB-ER-100 00. Wisconsin Department of Natural Resources, Bureau of Endangered Resources, Madison, WI.

Cochrane, T. S., and H. H. Iltis. 2000. Atlas of Wisconsin prairie and savanna flora. Technical Bulletin No. 191. Wisconsin Department of Natural Resources, Madison, WI.

Crother, B. I. (editor). 2008. Scientific and standard English names of amphibians and reptiles of North American north of Mexico. Herpetological Circular No. 37. Society for the Study of Amphibians and Reptiles, Salt Lake City, UT. < http://www.ssarherps .org/pdf/HC_37_6thEd.pdf> (22 September 2010).

Curtis, J. T. 1959. The vegetation of Wisconsin: an ordination of plant communities. University of Wisconsin Press, Madison, WI.

Davis, S. K. 2003. Nesting ecology of mixed-grass prairie songbirds in southern Saskatchewan. Wilson Bulletin 115:119-130.

Dechant, J. A., M. F. Dinkins, D. H. Johnson, L. D. Igl, C. M. Goldade, B. D. Parkin, and B. R. Euliss. 2003a. Effects of management practices on grassland birds: Upland Sandpiper. Northern Prairie Wildlife Research Center, Jamestown, ND. <http:// www.npwrc.usgs.gov/resource/literatr/grasbird/ upsa/upsa.htm > (15 December 2009).

Dechant, J. A., M. L. Sondreal, D. H. Johnson, L. D. Igl, C. M. Goldade, M. P. Nenneman, and B. R. Euliss. 2003b. Effects of management practices on grassland birds: Grasshopper Sparrow. Northern Prairie Wildlife Research Center, Jamestown, ND. <http://www.npwrc.usgs.gov/resource/literatr/ grasbird/grsp/grsp.htm> (15 December 2009).

Dechant, J. A., M. L. Sondreal, D. H. Johnson, L. D. Igl, C. M. Goldade, A. L. Zimmerman, and B. R. Euliss. 2003c. Effects of management practices on grassland birds: Bobolink. Northern Prairie Wildlife Research Center, Jamestown, ND. <http:// www.npwrc.usgs.gov/resource/literatr/grasbird/ bobo/bobo.htm> (15 December 2009).

Elbroch, M. 2003. Mammal tracks and sign, a guide to North American species. Stackpole Books, Mechanicsburg, PA.

Environmental Systems Research Institute. 1996. ArcView GIS. Environmental Systems Research Institute, Redlands, CA.

Farm Service Agency Online. 2007. Conservation Reserve Program fact sheet. <http://www.fsa.usda .gov/FSA/newsReleases?area $=$ newsroom\&subje $\mathrm{ct}=$ landing\&topic $=$ pfs\&newstype $=$ prfactsheet $\&$ type $=$ detail\&item5pf_20070525_consv_en_crp07

.html> (15 December 2009).

Fletcher, R. J., Jr., R. R. Koford, and D. A. Seaman. 2006. Critical demographic parameters for declining songbirds breeding in restored grasslands. Journal of Wildlife Management 70:145-157.

Forage and Grazing Terminology Committee. 1991. Terminology for grazing lands and grazing animals. Pocahontas Press, Inc., Blacksburg, VA.

Frawley, B. J. 1989. The dynamics of nongame bird breeding ecology in Iowa alfalfa fields. M.S. thesis, Iowa State University, Ames, IA.

Galligan, E. W., T. L. DeVault, and S. L. Lima. 2006. Nesting success of grassland and savanna birds on reclaimed surface coal mines of the Midwestern United States. Wilson Journal of Ornithology 118:537-546.

Gill, D. E., P. Blank, J. Parks, J .B. Guerard, B. Lohr, E. Schwartzman, J. G. Gruber, G. Dodge, C. A. Rewa, and H. F. Sears. 2006. Plants and breeding bird response on a managed Conservation Reserve Program grassland in Maryland. Wildlife Society Bulletin 34:944-956.

Giocomo, J. J., E. D. Moss, D. A. Buehler, and W. G. Minser. 2008. Nesting biology of grassland birds at Fort Campbell, Kentucky and Tennessee. Wilson Journal of Ornithology 120:111-119.

Giuliano, W. M., and S. E. Daves. 2002. Avian response to warm-season grass use in pasture and hayfield management. Biological Conservation 106:1-9.

Grant, T. A., E. M. Madden, T. L. Shaffer, P. J. Pietz, G. B. Berkley, and N. J. Kadrmas. 2006. Nest survival of Clay-colored and Vesper Sparrows in relation to woodland edge in mixed-grass prairies. Journal of Wildlife Management 70:691-701.

Henningsen, J. C., and L. B. Best. 2005. Grassland bird use of riparian filter strips in southeast Iowa. Journal of Wildlife Management 69:198-210.

Herkert, J. R. 2003. Effects of management practices on grassland birds: Henslow's Sparrow. Northern Prairie Wildlife Research Center, Jamestown, ND. <http://www.npwrc.usgs.gov/ resource/literatr/grasbird/hesp/hesp.htm $>$ (15 December 2009).

Herkert, J. R., D. L. Reinking, D. A. Wiedenfeld, M. Winter, J. L. Zimmerman, W. E. Jensen, E. J. Finck, R. R. Koford, D. H. Wolfe, S. K. Sherrod, M. A. Jenkins, J. Faaborg, and S. K. Robinson. 2003. Effects of prairie fragmentation on the nest success of breeding birds in the midcontinental Unites States. Conservation Biology 17:587-594.

Herkert, J. R., P. D. Vickery, and D. E. Kroodsma. 2002. Henslow's Sparrow (Ammodramus henslowii). Birds of North America No. 672, Academy of Natural Sciences, Philadelphia, PA. 
Heske, E. J., S. K. Robinson, and J. D. Brawn. 1999. Predator activity and predation on songbird nests in forest-field edges in east-central Illinois. Landscape Ecology 14:345-354.

Hull, S. D. 2003. Effects of management practices on grassland birds: Eastern Meadowlark. Northern Prairie Wildlife Research Center, Jamestown, ND. <http://www.npwrc.usgs.gov/resource/literatr/ grasbird/eame/eame.htm> (15 December 2009).

Igl, L. D., and D. H. Johnson. 1997. Changes in breeding bird populations in North Dakota: 1967 to 1992-93. Auk 114:74-92.

Johnson, D. H. 2001. Habitat fragmentation effects on birds in grassland and wetlands: a critique of our knowledge. Great Plains Research 11:211-231.

Johnson, D. H., and L. D. Igl. 1995. Contributions of the Conservation Reserve Program to populations of breeding birds in North Dakota. Wilson Bulletin 107:709-718.

Kershner, E. L., J. W. Walk, and R. E. Warner. 2004. Breeding season decisions, renesting, and fecundity of female Eastern Meadowlarks (Sturnella magna) in southeastern Illinois. Auk 121 796-805.

Koford, R. R. 1999. Density and fledging success of grassland birds in Conservation Reserve Program fields in North Dakota and west-central Minnesota. Studies in Avian Biology 19:187-195.

Lahti, D. C. 2001. The "edge effect on nest predation" hypothesis after twenty years. Biological Conservation 99:363-374.

Lahti, D. C. 2009. Why we have been unable to generalize about bird nest predation. Animal Conservation 12:279-281.

Larivière, S., and F. Messier. 1998. Denning ecology of the striped skunk in the prairies: implications for waterfowl nest predation. Journal of Applied Ecology 35:207-213.

Madden, E. M., R. K. Murphy, A. J. Hansen, and L. Murray. 2000. Models for guiding management of prairie bird habitat in northwestern North Dakota. American Midland Naturalist 144:377-392.

Martin, S. G., and Gavin, T. A. 1995. Bobolink (Dolichonyx oryzivorus). Birds of North America No. 176, Academy of Natural Sciences, Philadelphia, PA.

Martin, T. E. 1988. Processes organizing open-nesting bird assemblages: competition or nest predation? Evolutionary Ecology 2:37-50.

Martin, T. E. 1995. Avian life history evolution in relation to nest sites, nest predation, and food. Ecological Monographs 65:101-126.

Murie, O. J., and M. Elbroch. 2005. A field guide to animal tracks. Third edition. Houghton Mifflin Company, New York, NY.
Murphy, M. T. 2003. Avian population trends within the evolving agricultural landscape of eastern and central United States. Auk 120:20-34.

Murray, L. D., and L. B. Best. 2003. Short-term bird response to harvesting switchgrass for biomass in Iowa. Journal of Wildlife Management 67:611-621.

Niemuth, N. D., F. R. Quamen, D. E. Naugle, R. E. Reynolds, M. E. Estey, and T. L. Shaffer. 2007. Benefits of the Conservation Reserve Program to grassland bird populations in the Prairie Pothole Region of North Dakota and South Dakota. Final Report to the U.S. Department of Agriculture Farm Service Agency RFA OS-IA-04000000-N34.

Pasitschniak-Arts, M., and F. Messier. 1995. Risk of predation on waterfowl nests in the Canadian prairies: effects of habitat edges and agricultural practices. Oikos 73:347-355.

Patterson, M. P., and L. B. Best. 1996. Bird abundance and nesting success in Iowa CRP fields: the importance of vegetation structure and composition. American Midland Naturalist 135:153-167.

Perkins, D. W., and P. D. VIckery. 2007. Nest success of grassland birds in Florida dry prairie. Southeastern Naturalist 6:283-292.

Phillips, M. L., W. R. Clark, S. M. Nusser, M. A. Sovada, and R. J. Greenwood. 2004. Analysis of predator movement in prairie landscapes with contrasting grassland composition. Journal of Mammalogy 85:187-195.

Phillips, M. L., W. R. Clark, M. A. Sovada, D. J. Horn, R. R. Koford, and R. J. Greenwood. 2003. Predator selection of prairie landscape features and its relation to duck nest success. Journal of Wildlife Management 67:104-114.

Pietz, P. J., and D. A. Granfors. 2000. Identifying predators and fates of grassland passerine nests using miniature video cameras. Journal of Wildlife Management 64:71-87.

Renfrew, R. B., and C. A. Ribic. 2003. Grassland passerine nest predators near pasture edges identified on videotape. Auk 120:371-383.

Renfrew, R. B., and C. A. Ribic. 2008. Multi-scale models of grassland passerine abundance in a fragmented system in Wisconsin. Landscape Ecology 23:181-193.

Renfrew, R. B., C. A. Ribic, and J. L. Nack. 2005. Edge avoidance by nesting grassland birds: a futile strategy in a fragmented landscape. Auk 122:618-636.

Ribic, C. A., M. J. Guzy, and D. W. Sample. 2009a. Grassland bird use of remnant prairie and Conservation Reserve Program fields in an agricultural landscape in Wisconsin. American Midland Naturalist 161:110-122.

Ribic, C. A., R. R. Koford, J. R. Herkert, D. H. Johnson, N. D. Niemuth, D. Naugle, K. K. Bakker, D.W. 
Sample, and R.B. Renfrew. 2009b. Area sensitivity in North American grassland birds: patterns and processes. Auk 126:233-244.

Ribic, C. A. and D. W. Sample. 2001. Associations of grassland birds with landscape factors in southern Wisconsin. American Midland Naturalist 146:105-121.

Richardson, T. W., T. Gardali, and S. H. Jenkins. 2009. Review and meta-analysis of camera effects on avian nest success. Journal of Wildlife Management 73:287-293.

Robel, R. J., J. N. Briggs, A. D. Dayton, and L. C. Hulbert. 1970. Relationships between visual obstruction measurements and weight of grassland vegetation. Journal of Range Management 23:295-297.

Ryan, M. R. 1986. Nongame management in grassland ecosystems. Pp. 117-136 in J. B. Hale, L. B. Best, and R. L. Clawson (editors), Management of nongame wildlife in the Midwest: a developing art. North Central Section of The Wildlife Society, Bethesda, MD.

Sample, D. W. 1989. Grassland birds in southern Wisconsin: habitat preference, population trends, and response to land use changes. M.S. thesis, University of Wisconsin, Madison, WI.

Sample, D. W., and M. J. Mossman. 1997. Managing habitat for grassland birds: a guide for Wisconsin. Wisconsin Department of Natural Resources, Madison, WI.

Sample, D. W., C. A. Ribic, and R. B. Renfrew. 2003. Linking landscape management with the conservation of grassland birds in Wisconsin. Pp. 359-385 in J. A. Bissonette and I. Storch (editors), Landscape ecology and resource management: linking theory with practice. Island Press, Washington, DC.

Samson, F. B., and F. L. Knopf (editors). 1996. Prairie conservation: preserving North America's most endangered ecosystem. Island Press, Washington, DC.

Samson, F. B., F. L. Knopf, and W. R. Ostlie. 1998. Grasslands. Pp. 437-472 in M. J. Mac, P. Opler, C. E. Puckett Haecker, and P. D. Doran (editors), Status and trends of the nation's biological resources, Vol. 2. U.S. Geological Survey, Reston, VA.

Shaffer, T. 2004. A unified approach to analyzing nest success. Auk 121:526-540.
Skagen, S. K., S. K. Yackel Adams, and R. D. Adams. 2005. Nest survival relative to patch size in a highly fragmented shortgrass prairie landscape. Wilson Bulletin 117:23-34.

Stephens, S. E., D. N. Koons, J. J. Rotella, and D. W. Wiley. 2003. Effects of habitat fragmentation on avian nesting success: a review of the evidence at multiple spatial scales. Biological Conservation 115:101-110.

Swanson, D. A. 2003. Effects of management practices on grassland birds: Savannah Sparrow. Northern Prairie Wildlife Research Center, Jamestown, ND. <http://www.npwrc.usgs .gov/resource/literatr/grasbird/savs/savs.htm> (15 December 2009).

Thompson, F. R., III, and D. E. Burhans. 2003. Predation of songbird nests differs by predator and between field and forest habitats. Journal of Wildlife Management 67:408-416.

Thompson, F. R., III, W. Dijak, and D. E. Burhans. 1999. Video identification of predators at songbird nests in old fields. Auk 116:259-264.

Thompson, F. R., III, and C. A. Ribic. 2012. Conservation implications when the nest predators are known. Pp. 23-34 in C. A. Ribic, F. R. Thompson III, and P. J. Pietz (editors). Video surveillance of nesting birds. Studies in Avian Biology (no. 43), University of California Press, Berkeley, CA.

Walk, J. W., E. L. Kershner, T. J. Benson, and R. E. Warner. 2010. Nesting success of grassland birds in small patches in an agricultural landscape. Auk 127:328-334.

Walk, J. W., K. Wentworth, E. L. Kershner, E. K. Bollinger, and R. E. Warner. 2004. Renesting decisions and annual fecundity of female Dickcissels (Spiza americana) in Illinois. Auk 121:250-1261.

Whittingham, M. J., and K. L. Evans. 2004. The effects of habitat structure on predation risk of birds in agricultural landscapes. Ibis 146(Suppl. 2): 210-220.

Winter, M., and J. Faaborg. 1999. Patterns of area sensitivity in grassland-nesting birds. Conservation Biology 13:1424-1436.

Winter, M., D. H. Johnson, and J. Faaborg. 2000. Evidence for edge effects on multiple levels in tallgrass prairie. Condor 102:256-266. 